\title{
Accuracy of Pulse Oximetry in the Presence of Fetal Hemoglobin-A Systematic Review
}

\author{
Ena Pritišanac ${ }^{1,2}$, Berndt Urlesberger ${ }^{1,2}$, Bernhard Schwaberger ${ }^{1,2}\left(\mathbb{D}\right.$ and Gerhard Pichler ${ }^{1,2, *}$ \\ 1 Research Unit for Neonatal Micro- and Macrocirculation, Medical University of Graz, \\ Auenbruggerplatz 34/II, 8036 Graz, Austria; ena.pritisanac@medunigraz.at (E.P.); \\ berndt.urlesberger@medunigraz.at (B.U.); bernhard.schwaberger@medunigraz.at (B.S.) \\ 2 Division of Neonatology, Department of Pediatrics, University Hospital Graz, Auenbruggerplatz 30, \\ 8036 Graz, Austria \\ * Correspondence: gerhard.pichler@medunigraz.at; Tel.: +43-316-385-80520
}

Citation: Pritišanac, E.; Urlesberger, B.; Schwaberger, B.; Pichler, G. Accuracy of Pulse Oximetry in the Presence of Fetal Hemoglobin-A Systematic Review. Children 2021, 8 , 361. https://doi.org/10.3390/ children 8050361

Academic Editor: Joaquim M.

B. Pinheiro

Received: 3 March 2021

Accepted: 28 April 2021

Published: 30 April 2021

Publisher's Note: MDPI stays neutral with regard to jurisdictional claims in published maps and institutional affiliations.

Copyright: (c) 2021 by the authors. Licensee MDPI, Basel, Switzerland. This article is an open access article distributed under the terms and conditions of the Creative Commons Attribution (CC BY) license (https:/ / creativecommons.org/licenses/by/ $4.0 /)$.

\begin{abstract}
Continuous monitoring of arterial oxygen saturation by pulse oximetry $(\mathrm{SpO} 2)$ is the main method to guide respiratory and oxygen support in neonates during postnatal stabilization and after admission to neonatal intensive care unit. The accuracy of these devices is therefore crucial. The presence of fetal hemoglobin $(\mathrm{HbF})$ in neonatal blood might affect $\mathrm{SpO} 2$ readings. We performed a systematic qualitative review to investigate the impact of $\mathrm{HbF}$ on $\mathrm{SpO} 2$ accuracy in neonates. PubMed/Medline, Embase, Cumulative Index to Nursing \& Allied Health database (CINAHL) and Cochrane library databases were searched from inception to January 2021 for human studies in the English language, which compared arterial oxygen saturations (SaO2) from neonatal blood with $\mathrm{SpO} 2$ readings and included $\mathrm{HbF}$ measurements in their reports. Ten observational studies were included. Eight studies reported $\mathrm{SpO} 2-\mathrm{SaO} 2$ bias that ranged from $-3.6 \%$, standard deviation (SD) $2.3 \%$, to $+4.2 \%$ (SD 2.4). However, it remains unclear to what extent this depends on $\mathrm{HbF}$. Five studies showed that an increase in $\mathrm{HbF}$ changes the relation of partial oxygen pressure (paO2) to $\mathrm{SpO} 2$, which is physiologically explained by the leftward shift in oxygen dissociation curve. It is important to be aware of this shift when treating a neonate, especially for the lower SpO2 limits in preterm neonates to avoid undetected hypoxia.
\end{abstract}

Keywords: neonate; fetal hemoglobin; oxygen saturation monitoring; pulse oximetry

\section{Introduction}

Continuous arterial oxygen saturation measured by pulse oximetry (SpO2) is the primary monitoring to guide respiratory and oxygen support in neonates during postnatal stabilization and after admission to a neonatal intensive care unit (NICU) [1,2]. The recent resuscitation guidelines recommend specific pre-ductal SpO2 targets during postnatal transition based on the 25th percentile of $\mathrm{SpO} 2$ values in healthy term neonates that required no medical interventions at birth ( $2 \mathrm{~min} 65 \%, 5 \mathrm{~min} 85 \%, 10 \mathrm{~min} 90 \%$ ) [1,3].

Before the 1980s, transcutaneous oxygen tension measurement (tc-pO2) was a common monitoring method in the NICU. Because of the practical aspects (regular calibration and repositioning of the electrodes, skin irritations, underestimation of partial oxygen pressure ( $\mathrm{paO} 2$ ) in older neonatal patients) pulse oximetry was introduced into neonatal care as a better and more convenient monitoring method [4-7].

Pulse oximetry measures $\mathrm{SpO} 2$ by illuminating the tissue and detecting changes in the absorption of oxygenated and deoxygenated blood hemoglobin at two wavelengths: $660 \mathrm{~nm}$ (red) and $940 \mathrm{~nm}$ (infrared). In order to establish the pulse oximeter's measure of SpO2, the ratio of absorbance at these wavelengths is calculated and calibrated against direct measurements of arterial oxygen saturation from blood samples (SaO2). For this purpose, blood samples are taken from healthy adult volunteers under room air (normoxemia) and in artificially acquired hypoxic environments to achieve hypoxemia $[8,9]$. 
The difference (bias) between $\mathrm{SpO} 2$ and $\mathrm{SaO} 2$ reported in adults is $3-4 \%$, with a tendency for overestimation of SpO2 in critically ill mechanically ventilated patients [10-12]. However, studies conducted in mechanically ventilated neonates and children reported an even greater bias, particularly at lower SpO2 values. For instance, in the largest conducted study in children, the median bias of $\mathrm{SpO} 2$ versus $\mathrm{SaO} 2$ was as high as $6 \%$ for a $\mathrm{SpO} 2$ range of $81 \%$ to $85 \%$ [13]. Moreover, within the saturation target range for preterm infants (89-95\%), pulse oximetry exceeded the $4 \%$ error quality margin in the latest published study, which included 1908 neonates. SpO2 values were overestimated by an average of $2.9 \%$ with a standard deviation (SD) of $5.8 \%$ in this study [14].

The oxygen carrying capacity of blood depends primarily on the hemoglobin molecule. Fetal hemoglobin $(\mathrm{HbF})$ is the main oxygen carrier during pregnancy. From the 20th week of gestation, $\mathrm{HbF}$ is gradually replaced by adult hemoglobin $(\mathrm{HbA})$ and declines to its adult levels by approximately six months after birth $[15,16]$. HbF exhibits a significantly higher affinity for oxygen, which enables oxygen extraction from the blood of the mother to the fetus via the placenta at lower partial oxygen pressures and leads to the shift of the oxyhemoglobin dissociation curve (ODC) to the left (shown in Figure 1) [17,18].

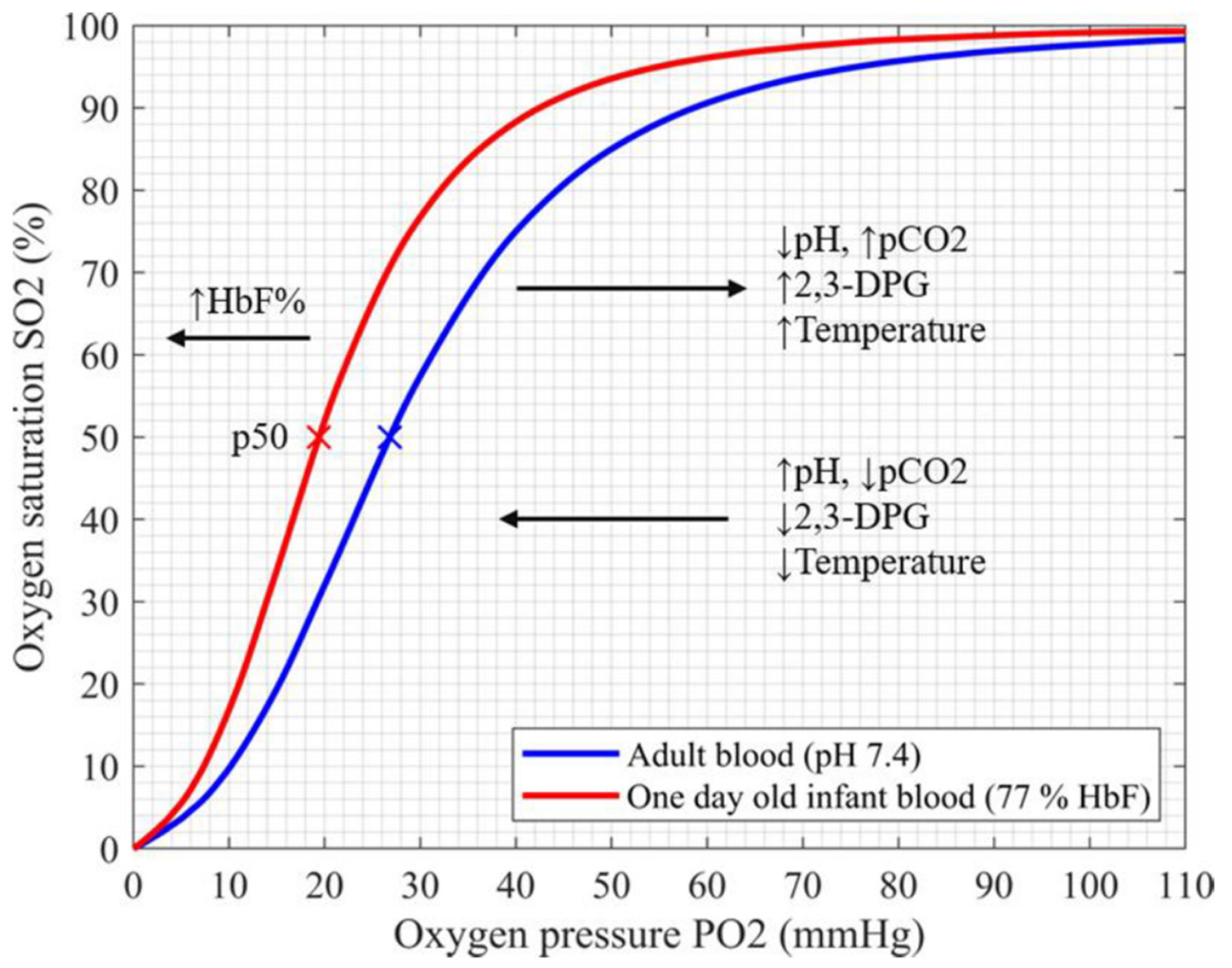

Figure 1. Oxyhemoglobin dissociation curve of fetal and adult hemoglobin shows the relationship between pO2 and $\mathrm{SO} 2$. For the saturation of $50 \%$, the corresponding $\mathrm{pO} 2$ values $(\mathrm{p} 50)$ are indicated $(\times)$. The factors that change the hemoglobin affinity for oxygen are indicated. $\mathrm{HbF}$ (red), fetal hemoglobin; $\mathrm{pCO} 2$, partial pressure of carbon dioxide; 2,3-DPG, diphosphoglycerate.

The prenatal $\mathrm{HbF}$ expression and conversion to $\mathrm{HbA}$ is regulated by a set of evolutionarily conserved genes and is not affected by the birth event itself. $\mathrm{HbF}$ values at birth are therefore particularly high in very low birth-weight neonates ( $\mathrm{HbF}>90 \%)$ [19]. However, in term neonates, these values can vary considerably among individuals, as reported in the largest conducted study in more than 150,000 newborns (mean $\mathrm{HbF} 82 \%$, range $5-100 \%$ ) [20]. Higher $\mathrm{HbF}$ values were observed in newborns exposed to risk factors 
for maternal or fetal hypoxia and for sudden infant death syndrome (SIDS) [21]. Furthermore, higher $\mathrm{HbF}$ values were reported to reduce the incidence of retinopathy of prematurity (ROP) in at-risk preterms, suggesting that $\mathrm{HbF}$ could be a protective factor for oxygen-related tissue injury in preterm neonates [22].

$\mathrm{HbF}$ content in the blood is often expressed as a percentage of total hemoglobin or fraction of fetal hemoglobin $(\mathrm{FHbF})$ and can be measured by several methods. These include the alkali denaturation method, electrophoresis, spectroscopy, and high-performance liquid chromatography, which is the most accurate method and the gold standard. The differentiation between fetal and adult hemoglobin in a sample is based on the existence of gamma-chain peaks, which are characteristic of $\mathrm{HbF}$. The level of $\mathrm{HbF}$ can be determined by measuring the total chromatogram gamma-globin chain areas expressed as a percentage of total $\mathrm{Hb}$ [23].

However, because of its wide availability, visible absorption spectroscopy performed by a hemoximeter or a blood-gas analyzer is the most commonly used method in clinical studies [24,25]. The optical system of a hemoximeter is designed to measure the concentration of total hemoglobin, oxygen saturation, and fractions of oxyhemoglobin, carboxyhemoglobin, deoxyhemoglobin, methemoglobin, and $\mathrm{HbF}$. $\mathrm{HbF}$ does not have the same visible absorption spectrum as $\mathrm{HbA}$ due to a slight variation in molecular structure [26]. If not taken into account, the presence of $\mathrm{HbF}$ in a sample will interfere with the results of oxygen saturation and the carboxyhemoglobin. Newer models of the hemoximeter (since 1992) use a linear relationship to adjust the $\mathrm{SaO} 2$ and oxyhemoglobin readings by the measured level of $\mathrm{HbF}$ [27].

Since the calibration curves of pulse oximeters use $\mathrm{SaO} 2$ measurements from the blood samples of healthy adults (with almost no $\mathrm{HbF}$ ), the accuracy of $\mathrm{SpO} 2$ values in the presence of $\mathrm{HbF}$ is questionable. The aim of this review was, therefore, to summarize the studies which examined the effect of $\mathrm{HbF}$ on pulse oximetry monitoring in human neonates.

\section{Materials and Methods}

Articles were identified using the stepwise approach specified in the Preferred Reporting Items for Systematic Reviews and Meta-Analyses (PRISMA) statement [28].

\subsection{Search Strategy}

A systematic search of Pubmed/Medline, Embase, Cumulative Index to Nursing \& Allied Health (CINAHL) and Cochrane library was performed from the date of inception of the databases to January 2021 to identify articles that concerned $\mathrm{HbF}$ and oxygen saturation monitoring by pulse oximetry in term and preterm neonates. Only human studies written in the English language were selected. Search terms included: newborn, neonate, preterm, term, infant, $\mathrm{HbF}$, hemoglobin $\mathrm{F}$, fetal hemoglobin, after birth, postnatal, oxygenation, arterial oxygen saturation, pulse oximetry, $\mathrm{SaO} 2$ and $\mathrm{SpO} 2$ (Supplementary Figure S1, Tables S1 and S2). Studies on fetal hemoglobin addressing sickle cell anemia and thalassemia were excluded. Additional published reports were identified through a manual search of references in retrieved articles and in review articles. The search was last updated on 24 January 2021.

\subsection{Study Selection}

Identified articles were independently evaluated by two authors (E.P., G.P.) by reviewing the titles and abstracts. If an uncertainty remained regarding the eligibility for inclusion, the full text was reviewed. The two reviewers independently selected relevant abstracts, critically appraised the full texts of the selected articles, and assessed the methodological quality of the studies. Data were analyzed qualitatively. Extracted data included the characterization of study type, patient characteristics, methods, and results. 


\section{Results}

Our initial search identified 2024 articles. After the removal of duplicates, 1822 articles were screened for inclusion. Exclusion criteria included absence of reliable $\mathrm{HbF}$ measurements or non-invasive oxygenation monitoring in term or preterm neonates (shown in Figure 2). Ten observational studies fulfilled the inclusion criteria [4-7,29-34]. No randomized controlled trial was identified. All studies performed measurements of $\mathrm{HbF}$ and non-invasive oxygen saturation monitoring by pulse oximetry at the upper and/or lower extremity in neonates in the first days and weeks after birth and determined blood oxygenation parameters. The study populations included preterm and term neonates with a range of gestational ages from 24 to 42 weeks of gestation. Studies are presented in Tables 1 and 2 according to the $\mathrm{HbF}$ measurement method.

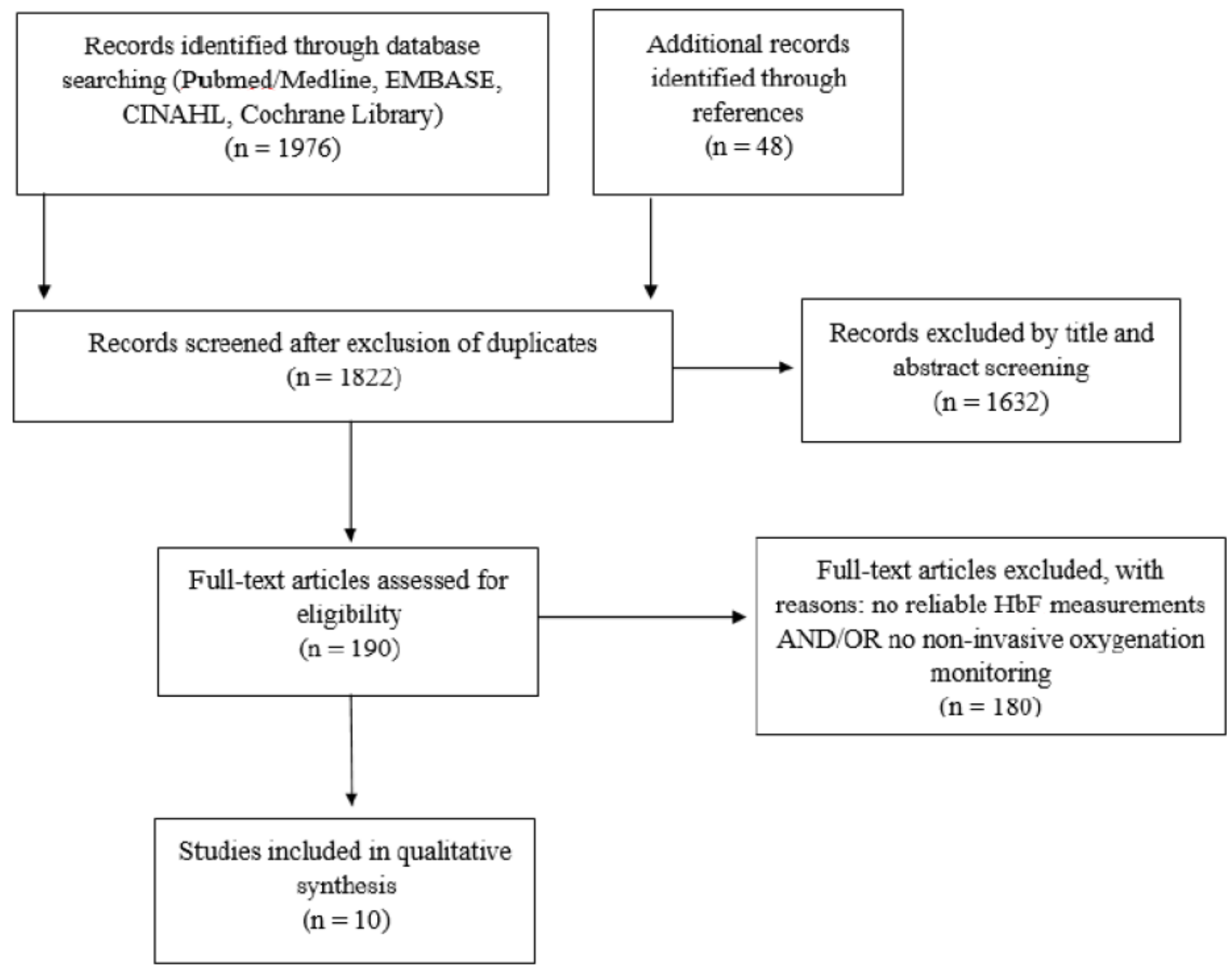

Figure 2. Study selection flow diagram. 
Table 1. Studies before 1992 comparing $\mathrm{SpO} 2$ monitoring to invasively measured blood oxygenation parameters.

\begin{tabular}{|c|c|c|c|c|c|c|c|c|c|c|c|}
\hline Ref & 1st Author, Year & $\begin{array}{c}\text { Number of } \\
\text { Patients/HbF } \\
\text { Blood Samples }\end{array}$ & $\begin{array}{l}\text { Blood Sample } \\
\text { Type }\end{array}$ & $\begin{array}{c}\mathrm{HbF} \\
\text { Measurement } \\
\text { Method }\end{array}$ & $\begin{array}{l}\text { Gestation } \\
\text { Distribution } \\
\text { (Weeks) }\end{array}$ & $\begin{array}{c}\text { Time of Sample } \\
\text { Collection and } \\
\text { Non-Invasive } \\
\text { Monitoring } \\
\end{array}$ & $\begin{array}{c}\text { Blood } \\
\text { Oxygenation } \\
\text { Parameters }\end{array}$ & $\begin{array}{c}\text { Blood Gas } \\
\text { Analyzer } \\
\text { /Hemoximeter }\end{array}$ & $\begin{array}{l}\text { Pulse Oximeter } \\
\text { (Company } \\
\text { Name) }\end{array}$ & $\begin{array}{c}\text { Additional Bedside } \\
\text { Oxygenation } \\
\text { Monitoring Device } \\
\text { (Company Name) } \\
\end{array}$ & Relevant Results \\
\hline [32]. & $\begin{array}{l}\text { Durand, } \\
1986\end{array}$ & $75 / 140$ & Arterial & $\begin{array}{l}\text { Alkali } \\
\text { denaturation } \\
\text { method }\end{array}$ & $24-42$ & $\begin{array}{l}1-14 \text { days }+ \\
30-153 \text { days } \\
\text { after birth }\end{array}$ & $\mathrm{paO} 2, \mathrm{SaO} 2$ & $\begin{array}{l}\text { Radiometer } \\
\text { BMS3 Mark II / } \\
\text { Co-oximeter } \\
\text { IL } 282\end{array}$ & $\begin{array}{l}\text { Nellcor N-100 } \\
\text { (Hayward, } \\
\text { CA, USA) }\end{array}$ & $\begin{array}{l}\text { tc-pO2 Oxygen } \\
\text { electrode (Novametrix, } \\
\text { Wallingford, CT, USA) }\end{array}$ & $\begin{array}{l}\mathrm{HbF} \text { values of } 4.3 \% \text { to } \\
95 \% \text { did not influence } \\
\text { the accuracy of pulse } \\
\text { oximeter readings. }\end{array}$ \\
\hline [7]. & $\begin{array}{c}\text { Ramanathan, } \\
1987\end{array}$ & $68 / 132$ & Arterial & $\begin{array}{l}\text { Alkali } \\
\text { denaturation } \\
\text { method }\end{array}$ & $25-31$ & $\begin{array}{c}1-6 \text { days }+20-80 \\
\text { days after birth }\end{array}$ & $\mathrm{paO} 2, \mathrm{SaO} 2$ & $\begin{array}{c}\text { Radiometer } \\
\text { BMS3 Mark II / } \\
\text { Co-oximeter } \\
\text { IL 282 }\end{array}$ & $\begin{array}{l}\text { Nellcor N-100 } \\
\text { (Hayward, } \\
\text { CA, USA) }\end{array}$ & $\begin{array}{l}\text { tc-pO2 Oxygen } \\
\text { electrode (Novametrix, } \\
\text { Wallingford, CT, USA) }\end{array}$ & $\begin{array}{l}\mathrm{HbF} \text { values of } 4.3 \% \text { to } \\
92.2 \% \text { did not influence } \\
\text { the accuracy of pulse } \\
\text { oximeter readings. }\end{array}$ \\
\hline [33]. & Wimberley, 1987 & $18 / 18$ & Arterial & $\begin{array}{l}\text { Alkali } \\
\text { denaturation } \\
\text { method }\end{array}$ & $25-34$ & $\begin{array}{l}\text { Within } 5 \text { days } \\
\text { after birth }\end{array}$ & $\mathrm{paO} 2, \mathrm{SaO} 2$ & $\begin{array}{l}\text { ABL300/ } \\
\text { Hemoximeter } \\
\text { OSM3 }\end{array}$ & $\begin{array}{c}\text { Ohmeda Biox } \\
\quad 3700\end{array}$ & $\begin{array}{c}\text { tc-pO2 Radiometer } \\
\text { TCM3 }\end{array}$ & $\begin{array}{l}\text { FHbF ranged from } \\
44-97 \% \text {. The variations } \\
\text { in the levels of } \mathrm{HbF}, \mathrm{pH}, \\
\text { pCO2 and 2,3-DPG } \\
\text { resulted in a variable } \\
\text { paO2-SaO2 relation. }\end{array}$ \\
\hline [4]. & $\begin{array}{l}\text { Jennis, } \\
1987\end{array}$ & $26 / 49$ & Arterial & Electrophoresis & $24-40$ & $\begin{array}{l}\text { 1-49 days after } \\
\text { birth }\end{array}$ & $\mathrm{SaO} 2$ & $\begin{array}{l}\text { Co-oximeter } \\
\text { IL-282 }\end{array}$ & $\begin{array}{l}\text { Nellcor N-100 } \\
\text { (Hayward, } \\
\text { CA, USA) }\end{array}$ & NA & $\begin{array}{l}\mathrm{FHbF}>50 \% \text { generated a } \\
2.8 \% \text { to } 3.6 \% \text { error } \\
\text { (underestimation) in } \\
\text { SpO2 reading. }\end{array}$ \\
\hline [5]. & $\begin{array}{l}\text { Praud, } \\
1989\end{array}$ & $71 / 52$ & Arterial & $\begin{array}{l}\text { Electrophoresis } \\
\text { and alkali } \\
\text { denaturation } \\
\text { method }\end{array}$ & $25-40$ & $\begin{array}{c}1-14 \text { days after } \\
\text { birth }+4.5-38 \\
\text { weeks after birth }\end{array}$ & $\mathrm{SaO} 2$ & $\begin{array}{l}\text { Hemoximeter } \\
\text { OSM2 }\end{array}$ & $\begin{array}{l}\text { Nellcor N-100 } \\
\text { (Hayward, } \\
\text { CA, USA) }\end{array}$ & NA & $\begin{array}{l}\text { For } \mathrm{FHbF}<50 \% \text { and } \\
\mathrm{SaO} 2 \leq 95 \% \text {, SpO2 } \\
\text { was overestimated. }\end{array}$ \\
\hline
\end{tabular}

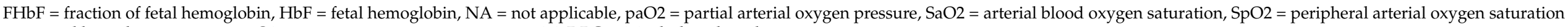
measured by pulse-oximetry, tc-pO2 = transcutaneous oxygen tension, 2,3-DPG = 2,3- diphosphogylcerate. 
Table 2. Hemoximetry studies (after 1992) comparing SpO2 monitoring to invasively measured blood oxygenation parameters.

\begin{tabular}{|c|c|c|c|c|c|c|c|c|c|c|c|}
\hline Ref & $\begin{array}{l}\text { 1st Author, } \\
\text { Year }\end{array}$ & $\begin{array}{c}\text { Number of } \\
\text { Patients/ HbF } \\
\text { Blood Samples }\end{array}$ & $\begin{array}{l}\text { Blood Sample } \\
\text { Type }\end{array}$ & $\begin{array}{c}\mathrm{HbF} \\
\text { Measurement } \\
\text { Method }\end{array}$ & $\begin{array}{l}\text { Gestation } \\
\text { Distribution } \\
\text { (Weeks) }\end{array}$ & $\begin{array}{l}\text { Time of Sample } \\
\text { Collection and } \\
\text { Non-Invasive } \\
\text { Monitoring }\end{array}$ & $\begin{array}{c}\text { Blood } \\
\text { Oxygenation } \\
\text { Parameters }\end{array}$ & $\begin{array}{l}\text { Blood Gas Ana- } \\
\text { lyzer/Hemoximeter }\end{array}$ & $\begin{array}{l}\text { Pulse Oximeter } \\
\text { (Company } \\
\text { Name) }\end{array}$ & $\begin{array}{l}\text { Additional Bedside } \\
\text { Oxygenation } \\
\text { Monitoring Device } \\
\text { (Company Name) }\end{array}$ & Relevant Results \\
\hline [6]. & $\begin{array}{l}\text { Rajadurai, } \\
1992\end{array}$ & $22 / 64$ & Arterial & $\begin{array}{c}\text { Visible } \\
\text { absorption } \\
\text { spectroscopy } \\
\text { (hemoximeter) }\end{array}$ & $25-36$ & $\begin{array}{l}1 \mathrm{~h}-73 \text { days } \\
\text { after birth }\end{array}$ & Functional $\mathrm{SaO} 2$ * & $\begin{array}{c}\text { ABL30 } \\
\text { Analyzer/ } \\
\text { Hemoximeter } \\
\text { OSM3 }\end{array}$ & $\begin{array}{l}\text { Nellcor N-100 } \\
\text { (Hayward, } \\
\text { CA, USA) }\end{array}$ & NA & $\begin{array}{c}\text { Pulse oximeter saturations } \\
\text { were unaffected by FHbF } \\
\text { values which ranged from } \\
0 \text { to } 100 \% \text {. }\end{array}$ \\
\hline [29]. & Shiao, 2005 & $20 / 210$ & $\begin{array}{l}\text { Arterial and } \\
\text { venous }\end{array}$ & $\begin{array}{l}\text { Visible } \\
\text { absorption } \\
\text { spectroscopy } \\
\text { (hemoximeter) }\end{array}$ & $24-34$ & $\begin{array}{l}\text { First } 5 \text { days after } \\
\text { birth }\end{array}$ & $\begin{array}{l}\mathrm{paO} 2, \mathrm{SaO} 2, \\
\mathrm{SvO} 2, \mathrm{HbO} 2\end{array}$ & $\begin{array}{l}\text { Hemoximeter } \\
\text { OSM3 }\end{array}$ & $\begin{array}{l}\text { Nellcor NPB } 290 \\
\text { (Pleasanton, } \\
\text { CA, USA) }\end{array}$ & NA & $\begin{array}{l}\text { Bias of } \mathrm{SpO} 2 \text { vs } \mathrm{HbO} 2 \text { was } \\
+1.6 \%(2 \mathrm{SD} 5.6) \text { and } \mathrm{SpO} 2 \text { vs } \\
\mathrm{SaO} 2-0.6 \%(2 \mathrm{SD} 5.9) \\
\text { There was no statistical } \\
\text { analysis of } \mathrm{HbF} \text { contribution } \\
\text { to the bias. }\end{array}$ \\
\hline [30]. & Shiao, 2006 & $39 / 188$ & $\begin{array}{l}\text { Arterial and } \\
\text { venous }\end{array}$ & $\begin{array}{l}\text { Visible } \\
\text { absorption } \\
\text { spectroscopy } \\
\text { (hemoximeter) } \\
\text { + HPLC }\end{array}$ & $25-38$ & $\begin{array}{l}\text { First } 5 \text { days } \\
\text { after birth }\end{array}$ & $\begin{array}{l}\mathrm{paO} 2, \mathrm{SaO} 2, \\
\mathrm{SvO} 2, \mathrm{HbO} 2\end{array}$ & $\begin{array}{l}\text { Hemoximeter } \\
\text { OSM3 }\end{array}$ & $\begin{array}{c}\text { Nellcor NPB } 290 \\
\text { (Tyco } \\
\text { Healthcare, } \\
\text { Mansfield, } \\
\text { MA, USA) }\end{array}$ & NA & $\begin{array}{l}\text { Lower } \mathrm{HbF} \text { levels after the } \\
\text { transfusion resulted in } \\
\text { lower } \mathrm{SpO} 2 \text { for the same } \\
\text { paO2 range of } 50-75 \mathrm{mmHg} \text {. } \\
\text { There was no statistical } \\
\text { analysis of } \mathrm{HbF} \text { contribution } \\
\text { to the } \mathrm{SpO} 2-\mathrm{SaO} 2 \text { bias. }\end{array}$ \\
\hline [31]. & Shiao, 2007 & $78 / 771$ & $\begin{array}{l}\text { Arterial and } \\
\text { venous }\end{array}$ & $\begin{array}{l}\text { Visible } \\
\text { absorption } \\
\text { spectroscopy } \\
\text { (hemoximeter) }\end{array}$ & $25-38$ & $\begin{array}{l}\text { First } 5 \text { days after } \\
\text { birth (every 6-8 h) }\end{array}$ & $\begin{array}{l}\mathrm{paO} 2, \mathrm{SaO} 2 \\
\mathrm{HbO} 2\end{array}$ & $\begin{array}{l}\text { Hemoximeter } \\
\text { OSM3 }\end{array}$ & $\begin{array}{l}\text { Nellcor (NPB } \\
\text { 290, Pleasanton, } \\
\text { CA, USA) }\end{array}$ & $\begin{array}{l}\mathrm{SaO} 2 \mathrm{~m}, \mathrm{SvO} 2 \mathrm{~m}{ }^{* * *} \\
\text { Oximetric } \\
\text { 3-wavelength } \\
\text { monitors (Abbott, } \\
\text { Chicago, } \\
\text { IL, USA) } \\
\end{array}$ & $\begin{array}{l}\text { Bias of } \mathrm{SpO} 2 \text { vs } \mathrm{HbO} 2 \text { in } \\
\text { arterial blood samples was } \\
\text { 2.5\% (SD 3.1). There was no } \\
\text { statistical analysis of HbF } \\
\text { contribution to the } \\
\text { SpO2-SaO2 bias. }\end{array}$ \\
\hline [34]. & $\begin{array}{l}\text { Nitzan, } \\
2018\end{array}$ & $14 / 28$ & Arterial & $\begin{array}{l}\text { Visible } \\
\text { absorption } \\
\text { spectroscopy } \\
\text { (hemoximeter) }\end{array}$ & $24-33$ & $\begin{array}{l}\text { Within } 12 \mathrm{~h} \text { before } \\
\text { and after the blood } \\
\text { transfusion (first } 5 \\
\text { days after birth) }\end{array}$ & $\mathrm{paO} 2, \mathrm{SaO} 2$ & ABL 90 FLEX & $\begin{array}{l}\text { Nellcor } \\
\text { (Covidien- } \\
\text { Medtronic, } \\
\text { Mansfield, } \\
\text { MA, USA) }\end{array}$ & NA & $\begin{array}{l}\mathrm{HbF} \text { declined significantly } \\
\text { after transfusion and } \mathrm{FiO} 2 \\
\text { increased by }>12 \% \text { to keep } \\
\mathrm{SpO} 2 \text { within the } \\
\text { same range. }\end{array}$ \\
\hline
\end{tabular}

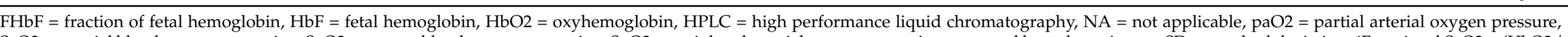

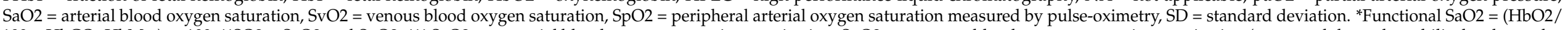

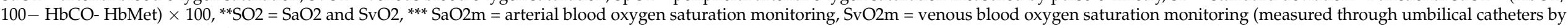
using Oximetric 3 monitors of 3-wavelength technology). 
Five studies conducted before 1992 used alkali denaturation or electrophoresis (Table 1), whereas five studies initiated after 1992 used a hemoximeter for the HbF measurement. (Table 2) All studies compared the non-invasive SpO2 readings to invasively measured blood oxygenation parameters, most commonly $\mathrm{SaO} 2$, and included $\mathrm{HbF}$ in the analyses.

One out of the five studies conducted before 1992 found a 2.8-3.6\% underestimation in $\mathrm{SpO} 2$ readings in relation to higher $\mathrm{HbF}$ levels [4], two found no bias in $\mathrm{SpO} 2$ readings in relation to $\mathrm{HbF}[7,32]$, and two reported inconclusive results [5,33]. Out of the five studies conducted after 1992, one reported no $\mathrm{SpO} 2-\mathrm{SaO} 2$ bias in relation to $\mathrm{HbF}$ [6], three studies reported an overestimation of $\mathrm{SpO} 2$ with higher $\mathrm{HbF}$ but did not provide statistical evidence to support this statement [29-31], and one study reported a decrease in SaO2$\mathrm{SpO} 2$ bias following transfusion of adult blood to the neonates and consequential $\mathrm{HbF}$ decline. It remains unclear whether this decrease can be attributed to $\mathrm{HbF}$ alone [34].

\section{Discussion}

To our knowledge, this is the first systematic review on the influence of $\mathrm{HbF}$ on $\mathrm{SpO} 2$ monitoring in human neonates. Based on the results of the majority of the included studies, a SpO2-SaO2 difference (bias) can be detected when the $\mathrm{SpO} 2(\%)$ readings are compared to the direct measurements of $\mathrm{SaO} 2(\%)$ or $\mathrm{HbO} 2(\%)$ in neonatal blood. Reported mean $\mathrm{SpO} 2-\mathrm{SaO} 2$ bias ranged from $-3.6 \%$ (SD 2.3) to $+4.2 \%$ (SD 2.4) (Table S2). Although there have been indications that the bias could be influenced by $\mathrm{HbF}$, none of the included studies provided an adequate statistical analysis to prove this statement.

We included ten studies in our analysis and divided them in two groups according to the technical characteristics and HbF measurement methods (Tables 1 and 2).

The five studies listed in Table 1 were conducted before the automatic correction of $\mathrm{SaO} 2$ for the presence of $\mathrm{HbF}$ by the hemoximeter (before 1992) [4,5,7,32,33]. Therefore, the corrections were performed retrospectively using a formula suggested by Cornellison et al. [35]. SpO2-SaO2 bias, which could be attributed to $\mathrm{HbF}$, was detected in two studies $[4,5]$. The first study found a SpO2 underestimation of $2.8 \%$ to $3.6 \%$ for higher $\mathrm{HbF}$ values $(\mathrm{FHbF}>50 \%)[4]$. The second study reported a SpO2 overestimation for the lower $\mathrm{HbF}$ values ( $\mathrm{FHbF}<50 \%, \mathrm{SpO} 2-\mathrm{SaO} 2$ bias $+4.2 \%$ (SD 2.4)) and a decrease in $\mathrm{SpO} 2-\mathrm{SaO} 2$ bias for the higher $\mathrm{HbF}$ (for $\mathrm{FHbF}>50 \%, \mathrm{SpO} 2-\mathrm{SaO} 2$ bias $+0.9 \%$ (SD 1.8)) [5]. Two of the five studies reported no significant effect of $\mathrm{HbF}$ on $\mathrm{SpO} 2$ accuracy [7,32]. Nevertheless, these two studies included patients with wide variations in $\mathrm{HbF}$ levels (FHbF 4-95\%) and reported only the mean difference between $\mathrm{SpO} 2$ and $\mathrm{SaO} 2$ for all patients. The fifth study of the period before 1992 observed the effects of multiple factors ( $\mathrm{HbF}, \mathrm{pH}, \mathrm{pCO} 2,2,3-\mathrm{DPG})$ on ODC in neonates and found that all of the parameters influenced ODC and therefore affected the corresponding SpO2 [33] (Figure 1). As the SpO2-SaO2 bias was not tested for $\mathrm{HbF}$ alone, the reported results are difficult to interpret.

Five studies conducted after 1992 used a hemoximeter for $\mathrm{HbF}$ measurements and adopted the automatic correction for $\mathrm{SaO} 2$ that accounts for the presence of $\mathrm{HbF}[6,29-31,34]$. Out of these, one study found pulse oximeter saturations to be unaffected by $\mathrm{HbF}$. It is important to mention that the 22 preterm neonates included in this study received multiple transfusions of adult blood which led to a rapid postnatal decline in $\mathrm{HbF}$ levels in the study population (FHbF 0-16\% after 2 weeks). Moreover, the study reported an average $\mathrm{SpO} 2-\mathrm{SaO} 2$ bias from all of the acquired measurements irrespective of the $\mathrm{HbF}$ level at the time of the blood sampling [6].

The three larger studies by Shiao et al. reported primarily an $\mathrm{HbF}$ effect on $\mathrm{SaO} 2$ and $\mathrm{HbO} 2$ measurements from neonatal blood samples [29-31]. Although the authors mentioned the SpO2-SaO2 and $\mathrm{SpO} 2-\mathrm{HbO} 2$ bias, there was no statistical evidence that these could be attributed to $\mathrm{HbF}$ alone.

In their first study on 210 neonatal blood samples, the authors compared different measurement modes of the hemoximeter: the $\mathrm{HbA}$-mode (adult mode) and the HbF-mode (fetal mode). They found that the blood saturation values were $4 \%$ to $7 \%$ higher using the $\mathrm{HbA}$-mode as compared to the $\mathrm{HbF}$ mode (which assumed $\mathrm{FHbF}$ of $80 \%$ ). The analyses 
with the $\mathrm{HbA}$-mode overestimated both arterial and venous saturation from neonatal blood samples. Regarding the SpO2-SaO2 comparisons, a SpO2-SaO2 bias of $-0.59 \%$ (2SD 5.93) for the $\mathrm{HbF}$ mode vs. $-5.69 \%$ (2SD 5.96) for the $\mathrm{HbA}$ mode was reported. However, the bias was tested only for the arterial saturation range of $97.5 \%$ (SD 3.16) and there was no statistical analysis of $\mathrm{HbF}$ contribution to the $\mathrm{SpO} 2-\mathrm{SaO} 2$ bias. Based on these results, it is difficult to assess pulse oximeters' accuracy for the different saturation ranges as well as the $\mathrm{HbF}$ contribution to the biases [29].

In their largest study, Shiao and $\mathrm{Ou}$ reported that the bias between $\mathrm{SpO} 2$ and $\mathrm{HbO} 2$ in arterial blood samples was as high as $2.5 \%$ (SD 3.1) for the arterial saturation range of 96.9\% (SD 3.18). However, any influence of $\mathrm{HbF}$ is only reported on blood-derived oxygen saturation parameters and was not tested for SpO2-SaO2 bias. Nevertheless, the authors presented several ODC based on the $\mathrm{paO} 2$ and $\mathrm{SaO} 2$ of their samples and showed that the ODC in neonates was not only left-shifted but also steeper when compared to adults. For paO2 values between 50 and $75 \mathrm{mmHg}$ (normoxemia), SpO2 ranged from 95\% to 97\% in neonates as compared to $85 \%$ to $94 \%$ in adults [31].

This narrow SpO2 range is based on the physiological characteristics of $\mathrm{HbF}$. The study conducted on blood samples of extremely low birth weight neonates with very high $\mathrm{HbF}$ levels showed that a paO2 of $41 \mathrm{mmHg}$ should be adequate to saturate $90 \% \mathrm{HbF}$ at a physiological $\mathrm{pH}$. Therefore, the paO2 range of 45 to $60 \mathrm{mmHg}$ could be defined as safe and preferable for this group of patients [36]. However, at paO2 of $50 \mathrm{mmHg}, \mathrm{HbF}$ is already $95 \%$ saturated. Consequently, further increase in $\mathrm{paO} 2$ leads to a minimal increase in saturation. (Figure 1) These observations further stress the importance of accurate SpO2 measurements and correct $\mathrm{SpO} 2$ targets to avoid undetected hypoxic or hyperoxic episodes.

Finally, the last included study, which investigated the effect of transfusion of adult blood and the consequential $\mathrm{HbF}$ decline on oxygenation parameters in neonates, found that there was a significant increase in paO2 after the transfusion $(51 \pm 8 \mathrm{mmHg}$ vs $57 \pm 7 \mathrm{mmHg}, p<0.001)$ with almost no changes in SpO2 $(94 \pm 2 \%$ vs $93 \pm 1 \%, p=0.4)$. This was achieved by an increase in $\mathrm{FiO} 2(>12 \%)$ applied to the infants to keep the SpO2 within the set goal [34]. However, it is not clear from this study whether the results reflect only the decrease in $\mathrm{HbF}$ or whether the changes in other parameters, such as $\mathrm{pH}$ or methemoglobin after the transfusion, might have influenced the described changes as well.

Based on the ten included studies, a SpO2-SaO2 bias can be detected by direct comparison of $\mathrm{SpO} 2$ readings to $\mathrm{SaO} 2$ in neonatal blood after the correction for $\mathrm{HbF}$, but it is unclear to what extent this can be attributed to the $\mathrm{HbF}$ alone. An increase in $\mathrm{HbF}$ changes the relation of $\mathrm{SpO} 2$ to paO2, which is physiologically explained by the leftward shift in the ODC. It is important to be aware of this shift when treating a neonate, especially for the lower SpO2 limits in preterm neonates. Because of the fetal ODC form (Figure 1), a potential undetected hypoxia is particularly pronounced in the lower saturation ranges, i.e. for $\mathrm{SpO} 2<90 \%$ where the curve is steep and becomes less detectable at its flat part (SpO2 > 95\%). From this point of view, it can be assumed that there is only a low risk of undetected hyperoxemia when using an upper alarm limit of $95 \%$. This was already shown in a study on three different pulse oximeters (Agilent Viridia, Masimo SET, Nellcor Oxismart), which detected hyperoxemia with 93-95\% sensitivity for the upper alarm limit of $95 \%$ [37].

The question of optimal oxygen-saturation targeting for preterm neonates in order to avoid hypoxic and/or hyperoxic organ damage has been a subject of numerous, large, randomized controlled clinical trials [38-44]. Lower SpO2 target ranges (85-89\%) have led to a decreased risk of retinopathy of prematurity but an increased risk of mortality [45]. If we took the ODC characteristics of $\mathrm{HbF}$ into account, the lower target ranges may have resulted in lower $\mathrm{SaO} 2$ values, as one would expect, and could have potentially resulted in more significant undetected hypoxemia in preterm infants. This may also have contributed to the reported increased rate of mortality and necrotizing enterocolitis in these patients. In addition, red blood cell transfusions, which are often required in preterm infants, lead to an increase in $\mathrm{HbA}$ relative to $\mathrm{HbF}$, thus resulting in an ODC shift to the right. If the 
SpO2 target ranges are set higher, the ODC shift to the right after a transfusion may lead to hyperoxemia and increase the incidence of retinopathy of prematurity.

Finally, there are additional limitations of the included studies. The changes in the ODC positions (and consequently of $\mathrm{SaO} 2$ ) based on the differences in $\mathrm{pH}$, temperature, and pCO2 (Figure 1) were not investigated in most of the studies. The studies also did not report the influence of oxygen supplementation on the $\mathrm{SpO}-\mathrm{SaO} 2$ bias. The largest study in neonates, which compared more than twenty-seven thousand $\mathrm{SpO} 2$ readings to $\mathrm{SaO} 2$ and $\mathrm{paO} 2$, however, reported a three-fold higher likelihood of $\mathrm{SpO} 2$ overestimation in infants treated with supplemental oxygen [14]. An additional explanation for the SpO2 differences in neonates and adults is that the sensors used in the calibration process of pulse oximeters have a different optical-path length in an adult compared to an infant, which may affect the accuracy of pulse oximeters in neonates $[9,46]$. As different measurement methods for $\mathrm{HbF}$ were used within the studies, this fact is a further limitation for the interpretation of the HbF levels and for the comparison of the studies. HPLC as a gold standard was only used in one study and when compared to the HbF measurements by a hemoximeter, a bias of $23 \%$ (SD 9) was detected [30].

\section{Conclusions}

In studies that compared non-invasive $\mathrm{SpO} 2$ monitoring by pulse oximetry to oxygen saturation measurements from blood samples in preterm and term infants and included $\mathrm{HbF}$ measurements in their reports, the majority found a $\mathrm{SpO} 2-\mathrm{SaO} 2$ bias, but it remains unclear whether this can be explained by the high fractions of $\mathrm{HbF}$ in neonatal blood alone. As hemoximeters today usually correct for the presence of $\mathrm{HbF}, \mathrm{SaO} 2$ values of those devices likely reflect the $\mathrm{paO} 2$ of neonatal blood correctly. Based on the physiological characteristics of fetal ODC, there might be an influence of $\mathrm{HbF}$ on $\mathrm{SpO} 2$ readings, resulting mostly in an overestimation of $\mathrm{SpO} 2$ for the lower saturation ranges. Further prospective studies on a larger sample size are needed to support this statement.

Supplementary Materials: The following are available online at https:/ /www.mdpi.com/article/10 .3390/children8050361/s1; Figure S1: table, Table S1: PRISMA Checklist. Table S2: Summary of the most important numerical data from the included studies.

Author Contributions: Conceptualized and designed the review, conducted systematic search of literature, drafted the initial manuscript, and reviewed and edited the manuscript, E.P. and G.P.; designed the tables and reviewed and edited the manuscript, E.P. and B.S.; critically reviewed the manuscript for important intellectual content, E.P., G.P., B.S. and B.U. All authors approved the final manuscript as submitted and agree to be accountable for all aspects of the work. All authors have read and agreed to the published version of the manuscript.

Funding: This research received no external funding.

Acknowledgments: The authors would like to thank Thomas Reid Alderson and Iva Pritišanac for critically reading the manuscript and Thomas Suppan for his help with the figures.

Conflicts of Interest: The authors declare no conflict of interest.

\section{References}

1. Madar, J.; Roehr, C.C.; Ainsworth, S.; Ersdal, H.; Morley, C.; Rüdiger, M.; Skåre, C.; Szczapa, T.; Te Pas, A.; Trevisanuto, D.; et al. European Resuscitation Council Guidelines 2021: Newborn resuscitation and support of transition of infants at birth. Resuscitation 2021, 161, 291-326. [CrossRef]

2. Aziz, K.; Lee, H.C.; Escobedo, M.B.; Hoover, A.V.; Kamath-Rayne, B.D.; Kapadia, V.S.; Magid, D.J.; Niermeyer, S.; Schmölzer, G.M.; Szyld, E.; et al. Part 5: Neonatal Resuscitation 2020 American Heart Association Guidelines for Cardiopulmonary Resuscitation and Emergency Cardiovascular Care. Pediatrics 2021, 147 (Suppl. 1), e2020038505E. [CrossRef] [PubMed]

3. Dawson, J.A.; Kamlin, C.O.F.; Vento, M.; Wong, C.; Cole, T.J.; Donath, S.M.; Davis, P.G.; Morley, C.J. Defining the reference range for oxygen saturation for infants after birth. Pediatrics 2010, 125, e1340-e1347. [CrossRef] [PubMed]

4. Jennis, M.S.; Peabody, J.L. Pulse oximetry: An alternative method for the assessment of oxygenation in newborn infants. J. Pediatr. $1987,79,524-528$. 
5. Praud, J.P.; Gaultier, C.L.; Carofilis, A.; Lacaille, F.; Dehan, M.; Bridey, F. Accuracy of two wavelength pulse oximetry in neonates and infants. Pediatr. Pulmonol. 1989, 6, 180-182. [CrossRef]

6. Rajadurai, V.S.; Walker, A.M.; Yu, V.Y.H.; Oates, A. Effect of fetal hemoglobin on the accuracy of pulse oximetry in preterm infants. J. Paediatr. Child Health 1992, 28, 43-46. [CrossRef]

7. Ramanathan, R.; Durand, M.; Larrazabal, C. Pulse oximetry in very low birth weight infants with acute and chronic lung injury. Pediatrics 1987, 79, 612-617.

8. Wukitsch, M.W.; Petterson, M.T.; Tobler, D.R.; Pologe, J.A. Pulse oximetry: Analysis of theory, technology, and practice. J. Clin. Monit. 1988, 4, 290-301. [CrossRef] [PubMed]

9. Nitzan, M.; Romem, A.; Koppel, R. Pulse oximetry: Fundamentals and technology update. Med. Devices 2014, 7, 231-239. [CrossRef]

10. Louw, A.; Cracco, C.; Cerf, C.; Harf, A.; Duvaldestin, P.; Lemaire, F.; Brochard, L. Accuracy of pulse oximetry in the intensive care unit. Intensive Care Med. 2001, 27, 1606-1613. [CrossRef]

11. Perkins, G.D.; McAuley, D.F.; Giles, S.; Routledge, H.; Gao, F. Do changes in pulse oximeter oxygen saturation predict equivalent changes in arterial oxygen saturation? Crit. Care 2003, 7, R67. [CrossRef] [PubMed]

12. Jubran, A.; Tobin, M.J. Reliability of pulse oximetry in titrating supplemental oxygen therapy in ventilator-dependent patients. Chest 1990, 97, 1420-1425. [CrossRef] [PubMed]

13. Ross, P.; Newth, C.; Khemani, R. Accuracy of pulse oximetry in children. Pediatrics 2014, 133, 22-29. [CrossRef] [PubMed]

14. Wackernagel, D.; Blennow, M.; Hellström, A. Accuracy of pulse oximetry in preterm and term infants is insufficient to de-termine arterial oxygen saturation and tension. Acta Paediatr. 2020, 109, 2251-2257. [CrossRef] [PubMed]

15. Oski, F.A.; Delivoria-Papadopoulos, M. The shift to the left. Pediatrics 1971, 48, 853-856. [PubMed]

16. Sankaran, V.G.; Orkin, S.H. The Switch From Fetal to Adult Hemoglobin. Cold Spring Harb. Perspect. Med. 2013, 3, a011643. [CrossRef]

17. Bunn, H.F.; Briehl, R.W. The interaction of 2,3-diphosphoglycerate with various human hemoglobins. J. Clin. Investig. 1970, 49, 1088-1095. [CrossRef]

18. Orzalesi, M.M.; Hay, W.W. The regulation of oxygen affinity of fetal blood. I. In vitro experiments and results in normal infants. Pediatrics 1971, 48, 857-864.

19. Bard, H. Postnatal fetal and adult hemoglobin synthesis in early preterm newborn infants. J. Clin. Investig. 1973, 52, 1789-1795. [CrossRef]

20. Wilson, K.; Hawken, S.; Murphy, M.S.; Atkinson, K.M.; Potter, B.K.; Sprague, A.; Walker, M.; Chakraborty, P.; Little, J. Postnatal prediction of gestational age using newborn fetal hemoglobin levels. EBioMedicine 2017. [CrossRef]

21. Cochran-Black, D.L.; Cowan, L.D.; Neas, B.R. The relation between newborn hemoglobin F fractions and risk factors for sudden infant death syndrome. Arch. Pathol. Lab. Med. 2001, 125, 211-217. [CrossRef] [PubMed]

22. Stutchfield, C.J.; Jain, A.; Odd, D.; Wiliams, C.; Markham, R. Foetal haemoglobin, blood transfusion, and retinopathy of prematurity in very preterm infants: A pilot prospective cohort study. Eye 2017, 31, 1451-1455. [CrossRef] [PubMed]

23. Inoue, H.; Takabe, F.; Maeno, Y.; Iwasa, M. Identification of fetal hemoglobin in blood stains by high performance liquid chro-matography. Z. Rechtsmed. 1989, 102, 437-444. [CrossRef] [PubMed]

24. Davis, M.D.; Walsh, B.K.; Sittig, S.E.; Restrepo, R.D. AARC Clinical practice guideline: Blood gas analysis and hemoximetry: 2013. Respir. Care 2013, 58, 1694-1703. [CrossRef]

25. ABL800 FLEX Reference Manual from Software Version 6.00; Code number: 989-963; Radiometer: Copenhagen, Denmark, 2008.

26. Zijlstra, W.G.; Buursma, A.; Meeuwsen-van der Roest, W.P. Absorption spectra of human fetal and adult oxyhemoglobin, de-oxyhemoglobin, carboxyhemoglobin, and methemoglobin. Clin. Chem. 1991, 37, 1633-1638. [CrossRef]

27. Krzeminski, A. How Is Fetal Hemoglobin Determined and Corrected for in the OSM3, the ABL 510, and the ABL 520? Radiometer: Copenhagen, Denmark, 1992; pp. 1-4.

28. Moher, D.; Shamseer, L.; Clarke, M.; Ghersi, D.; Liberati, A.; Petticrew, M.; Shekelle, P.; Stewart, L.A. Preferred reporting items for systematic review and meta-analysis-protocols (Prisma P) 2015 statement. Syst. Rev. 2015, 4, 1. [CrossRef]

29. Shiao, S.Y.P.K. Effects of fetal hemoglobin on accurate measurements of oxygen saturation in neonates. J. Perinat. Neonatal Nurs. 2005, 19, 348-361. [CrossRef]

30. Shiao, S.Y.P.K.; Ou, C.N.; Pierantoni, H. The measurement of accurate fetal hemoglobin and related oxygen saturation by the hemoximeter. Clin. Chim. Acta 2006, 374, 75-80. [CrossRef]

31. Shiao, S.Y.; Ou, C.N. Validation of oxygen saturation monitoring in neonates. Am. J. Crit. Care 2007, 16, 168-178. [CrossRef]

32. Durand, M.; Ramanathan, R. Pulse oximetry for continuous oxygen monitoring in sick newborn infants. J. Pediatr. 1986, 109, 1052-1056. [CrossRef]

33. Wimberley, P.D.; Helledie, N.R.; Friis-Hansen, B.; Fogh-Andersen, N.; Olesen, H. Pulse oximetry versus transcutaneous pO2 in sick newborn infants. Scand. J. Clin. Lab. Investig. 1987, 188, 19-25. [CrossRef]

34. Nitzan, I.; Hammerman, C.; Mimouni, F.B.; Bin-Nun, A. Packed red blood cells transfusions in neonates: Effect on FiO2 and $\mathrm{PaO} 2 / \mathrm{SaO} 2$ ratio and implications for neonatal saturation targeting. J. Perinatol. 2018, 38, 693-695. [CrossRef]

35. Cornelissen, P.J.H.; van Woensel, C.L.M.; van Oel, W.C.; de Jong, P.A. Correction factors for hemoglobin derivatives in fetal blood, as measured with the IL 282 Co-oximeter. Clin. Chem. 1983, 29, 1555-1556. [CrossRef] 
36. Émond, D.; Lachance, C.; Gagnon, J.; Bard, H. Arterial partial pressure of oxygen required to achieve $90 \%$ saturation of hae-moglobin in very low birth weight newborns. Pediatrics 1993, 91, 602-604.

37. Bohnhorst, B.; Peter, C.S.; Poets, C.F. Detection of hyperoxaemia in neonates: Data from three new pulse oximeters. Arch. Dis. Child. Fetal Neonatal Ed. 2002, 87, F217-F219. [CrossRef] [PubMed]

38. Support Study Group of the Eunice Kennedy Shriver NICHD Neonatal Research Network; Carlo, W.A.; Finer, N.N.; Walsh, M.C.; Rich, W.; Gantz, M.G.; Laptook, A.R.; Yoder, B.A.; Faix, R.G.; Das, A.; et al. Target ranges of oxygen saturation in extremely pre-term infants. N. Engl. J. Med. 2010, 362, 1959-1969.

39. Vaucher, Y.E.; Peralta-Carcelen, M.; Finer, N.N.; Carlo, W.A.; Gantz, M.G.; Walsh, M.C.; Laptook, A.R.; Yoder, B.A.; Faix, R.G.; Das, A.; et al. Neurodevelopmental outcomes in the early CPAP and pulse oximetry trial. N. Engl. J. Med. 2012, 367, 2495-2504. [CrossRef] [PubMed]

40. Schmidt, B.; Whyte, R.K.; Asztalos, E.V.; Moddemann, D.; Poets, C.; Rabi, Y.; Solimano, A.; Roberts, R.S.; the Canadian Oxygen Trial (COT) Group. Effects of targeting higher vs lower arterial oxygen saturations on death or disability in extremely preterm infants: A randomized clinical trial. JAMA 2013, 309, 2111-2120. [CrossRef]

41. Group BIUKC; Group BIAC; Group BINZC; Stenson, B.J.; Tarnow-Mordi, W.O.; Darlow, B.A.; Simes, J.; Juszczak, E.; Askie, L.; Battin, M.; et al. Oxygen saturation and outcomes in preterm infants. N. Engl. J. Med. 2013, 368, 2094-2104.

42. Darlow, B.A.; Marschner, S.L.; Donoghoe, M.; Battin, M.R.; Broadbent, R.S.; Elder, M.J.; Hewson, M.P.; Meyer, M.P.; Ghadge, A.; Graham, P.; et al. Randomized controlled trial of oxygen saturation targets in very pre-term infants: Two year outcomes. J. Pediatr. 2014, 165, 30-35. [CrossRef] [PubMed]

43. The BOOST-II Australia and United Kingdom Collaborative Groups; Tarnow-Mordi, W.O.; Stenson, B.J.; Kirby, A.; Juszczak, E.; Donoghoe, M.; Deshpande, S.; Morley, C.; King, A.; Doyle, L.W.; et al. Outcomes of two trials of oxygen-saturation targets in preterm infants. N. Engl. J. Med. 2016, 374, 749-760. [PubMed]

44. Khadawardi, E.; Al Hazzani, F. Oxygen saturation and outcomes in preterm infants: The BOOST II United Kingdom, Australia, and New Zealand Collaborative Groups. J. Clin. Neonatol. 2013, 2, 73-75. [CrossRef]

45. Lakshminrusimha, S.; Manja, V.; Mathew, B.; Suresh, G.K. Oxygen targeting in preterm infants: A physiologic interpretation. J. Perinatol. 2015, 35, 8-15. [CrossRef] [PubMed]

46. Poets, C.F. Noninvasive monitoring and assessment of oxygenation in infants. Clin. Perinatol. 2019, 46, 417-433. [CrossRef] [PubMed] 